\title{
Dermatoscopia
}

\section{ENTOMODERMATOSCOPIA - UM NOVO MÉTODO DE DIAGNÓSTICO EM DERMATOLOGIA GERAL}

\author{
Virgínia Coelho de Sousa', André Laureano Oliveira², Jorge Cardoso ${ }^{3}$ \\ 'Interna do Internato Complementar de Dermatovenereologia/Resident of Dermatology and Venereology \\ ${ }^{2}$ Assistente Hospitalar de Dermatologia e Venereologia/Consultant of Dermatology and Venereology \\ ${ }^{3}$ Chefe de Serviço de Dermatologia e Venereologia/Consultant Chief of Dermatology and Venereology \\ Serviço de Dermatologia e Venereologia/Department of Dermatology and Venereology, Hospital de Santo António dos Capuchos, \\ Centro Hospitalar de Lisboa Central, Lisboa, Portugal
}

RESUMO - Entre as diversas aplicações da dermatoscopia, distinguem-se cinco campos: dermatoscopia nas infeções e infestações (entomodermatoscopia), nas doenças inflamatórias da pele (inflamoscopia), na patologia do cabelo (tricoscopia), na avaliação da prega ungueal (capilaroscopia), e a sua aplicação na monitorização da resposta à terapêutica não cirúrgica no cancro cutâneo.

O termo entomodermatoscopia deriva das palavras dermatoscopia e entomologia, tendo sido introduzido para descrever a aplicação da primeira no diagnóstico das patologias infeciosas da pele. Assim, descrevemos casos clínicos que demonstram a sua utilidade reconhecida no diagnóstico de molusco contagioso, escabiose, pediculose, verrugas virais e leishmaniose cutânea.

PALAVRAS-CHAVE - Dermatoscopia; Doenças Infecciosas da Pele; Escabiose; Leishmaniose Cutânea; Molusco Contagioso; Verrugas.

\section{ENTOMODERMOSCOPY - A NEW TOLL FOR THE DIAGNOSIS IN GENERAL DERMATOLOGY}

ABSTRACT - Among the new applications of dermoscopy, five main fields can be distinguished: dermoscopy of skin infections and infestations (entomodermoscopy), inflammatory skin diseases (inflammoscopy), hair disorders (trichoscopy), nailfold cappilaries (capillaroscopy), and dermoscopy for treatment decisions or treatment monitoring.

The term entomodermoscopy, from the words dermoscopy and entomology, has been introduced to describe the use of dermoscopy in the diagnosis of infectious skin disorders. Herein, we report several cases concerning its applicability in the diagnosis of molluscum contagiosum, scabies, lice infestations, viral warts and early cutaneous leishmaniasis.

KEY-WORDS - Dermoscopy; Leishmaniasis, Cutaneous; Molluscum Contagiosum; Skin Diseases, Infectious; Scabies; Warts.

Conflitos de interesse: Os autores declaram não possuir conflitos de interesse. No conflicts of interest.

Suporte financeiro: O presente trabalho não foi suportado por nenhum subsídio ou bolsa. No sponsorship or scholarship granted. Direito à privacidade e consentimento escrito / Privacy policy and informed consent: Os autores declaram que pediram consentimento ao doente para usar as imagens no artigo. The authors declare that the patient gave written informed consent for the use of its photos in this article.

Recebido/Received - Julho/July 2015; Aceite/Accepted - Setembro/September 2015

Correspondência:

Dr. ${ }^{a}$ Virgínia Coelho de Sousa

Alameda de Santo António dos Capuchos

$1169-050$ - Lisboa, Portugal

Tel.: +351213136300

Fax +351213562208

Email: virginiacoelhodesousa@gmail.com 


\section{Dermatoscopia}

\section{INTRODUCTION}

The wide acceptance of dermoscopy as a complementary method of diagnosis in neoplastic skin disease led to its application in other fields of dermatology, including inflammatory and infectious skin disease.

New generations of commercially available hand-held dermoscopes operate at 10-fold magnification and do not require a direct contact between the optical lens and the skin or mucosal surface. These devices use polarized light and can be therefore applied without the risk of possible cross-infection.

We highlight dermoscopy as a complementary tool in the diagnosis of skin infections and infestations. Entomodermoscopy is a term derived from the words "entomology" and "dermoscopy". This term is used to describe the applicability of dermoscopy in this field of dermatology. ${ }^{1}$ Herein, we selected several cases that show its recognized utility in the diagnosis of scabies, lice infestations, molluscum contagiosum, viral warts (common, plane and plantar) and early leishmaniasis.

\section{Scabies}

A 55 years-old female presented with a 2-week history of an extremely pruritic eruption, consisting of multiple papules on the wrists, fingerweb spaces, genital area and waist. Linear burrows were absent on clinical examination (Fig. 1A).

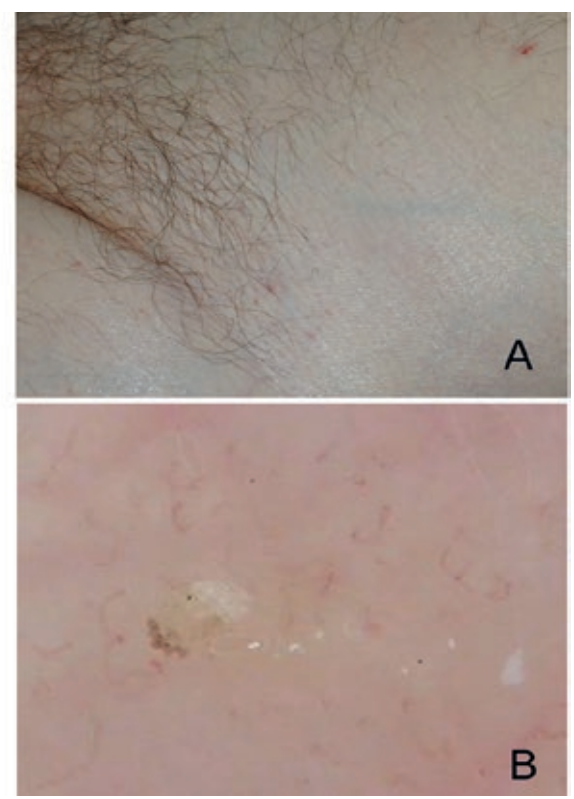

Fig 1 - Scabies. A) Papules on the inguinal area. No linear burrows were seen; B) Dermoscopy disclosed a dark brown triangular structure located at the end of a whitish structureless curved line, reminiscent of a jet with contrail. The brown triangle corresponds to the dorsal section of the mite Sarcoptes scabiei var hominis.
Dermoscopy showed a small dark brown triangular structure, located at the end of a whitish structureless curved line, reminiscent of a jet with contrail (Fig. 1B). These features favored the diagnosis of scabies. ${ }^{2}$
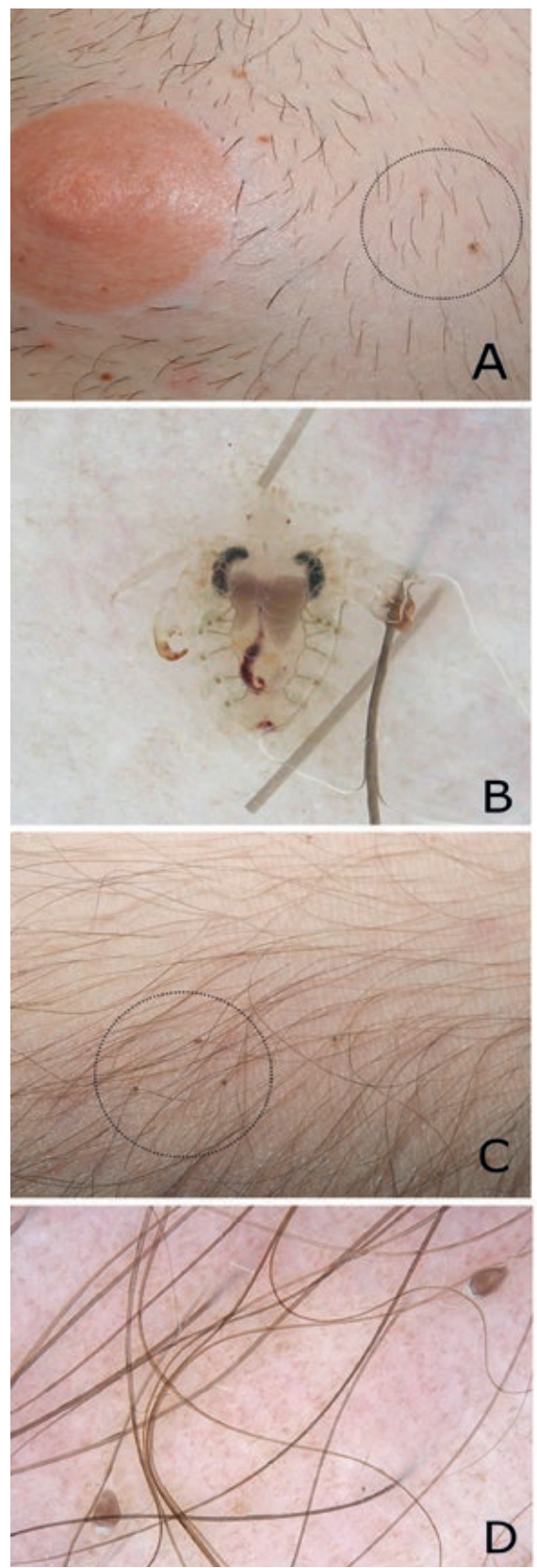

Fig 2 - Pediculosis. A) Adult lice; B) Dermoscopy showed body louse with plane body and pincer-like claws attached to hairs. Note the respiratory spiracles and circulatory system; C) Nits at the base of the hair shafts; D) Dermoscopy disclosed ovoid brown structures, corresponding to vital nits. 


\section{Dermatoscopia}

Scabies is a skin infestation caused by the host-specific mite Sarcoptes scabiei var hominis. The brown hang-glider like triangle corresponds to the pigmented anterior dorsal section of the mite. This pigmented section is composed by the mouth and front legs of the mite. The contrail correlates to the burrow in the cornified layer, eventually filled with eggs and fecal pellets. The later appear as small brown dots in dermoscopy. ${ }^{3}$

\section{Phthirius pubis ("Crab Lice" or "Pubic Lice")}

A 25 years-old male presented with a 7-day history of multiple pinpoint red macules and excoriations, located on the pubic region, chest, axillae and forearms. The patient reported intense pruritus. Adult lice (Fig. 2A) and nits (Fig. 2C) were seen on clinical examination.

Dermoscopy of pubic lice disclosed parasites with plane body (Fig. 2B) and pincer-like claws attached to hairs. Vital nits at the base of hair shafts were also seen (Fig. 2D). The vital nits are identified as brown ovoid structures, while empty nits are translucent and typically show a plane and fissured free ending. This data is also important in the monitoring of therapy efficacy. Identification of vital nits should lead to therapy maintenance or modification. ${ }^{4}$

\section{Molluscum contagiosum}

A 21 years-old immunocompetent male presented with multiple, asymptomatic dome shaped and umbilicated yellowish papules on the trunk, neck and face (Fig. 3A). Dermoscopy show central polylobular white to yellowish amorphous structures, surrounded by linear, fine, blurred, peripheral crown vessels not crossing the center (Fig. 3B). These structures supported the diagnosis of Molluscum contagiosum (MC). ${ }^{5}$

A rare presentation on the nipple was seen in other male patient, presenting with an asymptomatic skin color papule (Fig. 4A). Dermoscopy aided in the correct diagnosis, showing similar features to the case previously described (Fig.

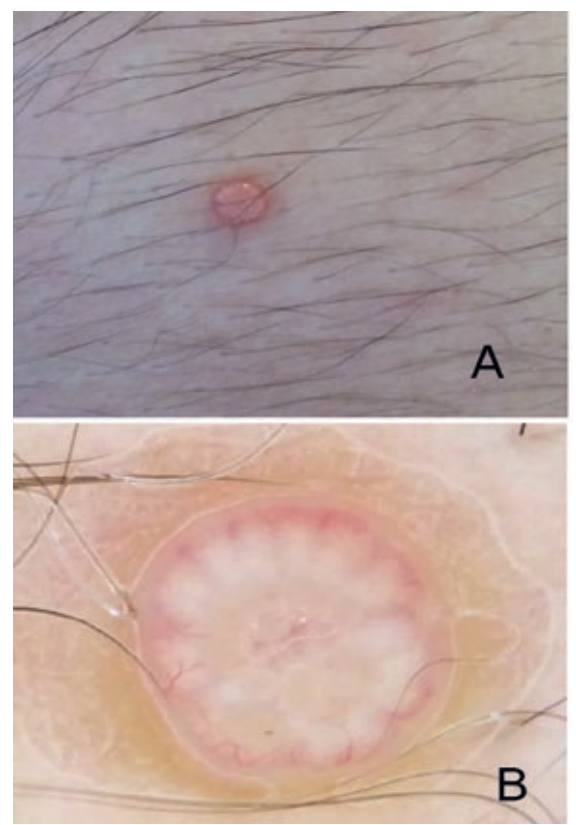

Fig 3 - Molluscum contagiosum. A) Umbilicated yellowish papule on the trunk; B) Dermoscopy disclosed polylobular white to yellowish amorphous structures, surrounded by linear, fine, blurred, peripheral crown vessels not crossing the center. These features are consistent with molluscum contagiosum.

4B). To the best of our knowledge, only five female patients have been reported with MC on the nipple (2 patients) or areola (3 patients). ${ }^{6}$

\section{Common and plantar warts}

A 37 years-old man reported a. 6-month history of a hyperkeratotic papule on the right shoulder (Fig. 5A).

Dermoscopy revealed multiple, irregularly distributed
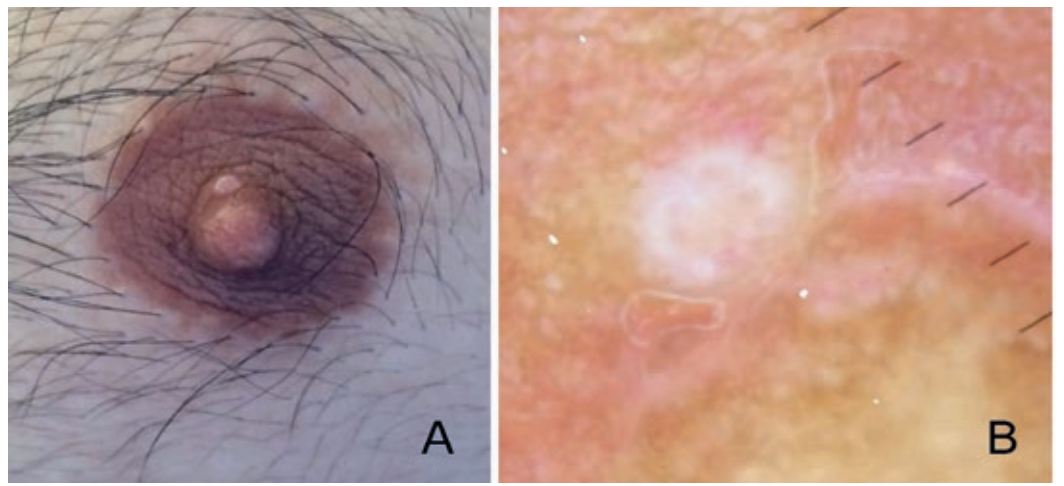

Fig. 4 - Molluscum contagiosum. A) Rare presentation of molluscum in the nipple; B) Dermoscopic features of molluscum on the nipple. 


\section{Dermatoscopia}
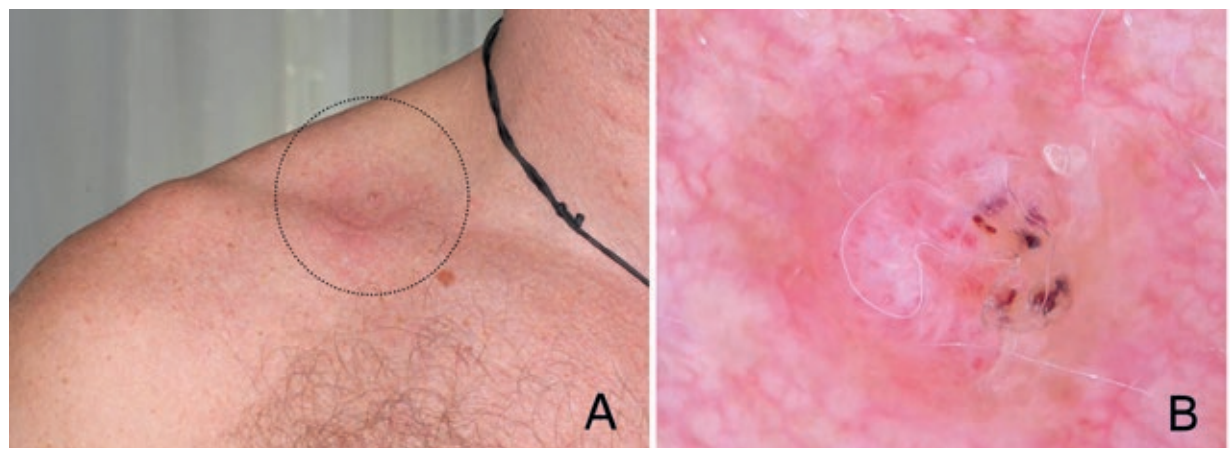

Fig 5 - Common warts. A) Hyperkeratotic papule on the right shoulder; B) Dermoscopy showed irregularly distributed dotted and hairpin vessels surrounded by a white halo, supporting the diagnosis of a common wart.

dotted and hairpin vessels surrounded by a white halo (Fig. 5B). This vascular pattern supported the clinical diagnosis of a common wart. $^{7}$

A 62 year-old female presented with hyperkeratotic plane plaque on the dorsal surface of the right hand (Fig. 6A). On dermoscopy it was apparent a mosaic pattern on a yellow background. Red dots and red curved lines were visible in the center, corresponding to dotted and hairpin vessels (Fig. 6B). These features favored the diagnosis of a plane wart. ${ }^{8}$ The yellow background with red dots in the center is typical for plane warts, allowing a differentiation from comedo or folliculitis, particularly when the lesions are located on the face. Comedo and folliculitis lack the red dots, showing a round yellow structure in the center that correlates with the keratin plug or pus in the infundibulum.'

An 18 years-old man presented with painful, hyperkeratotic plaque on the right sole. Dermoscopy disclosed a yellowish
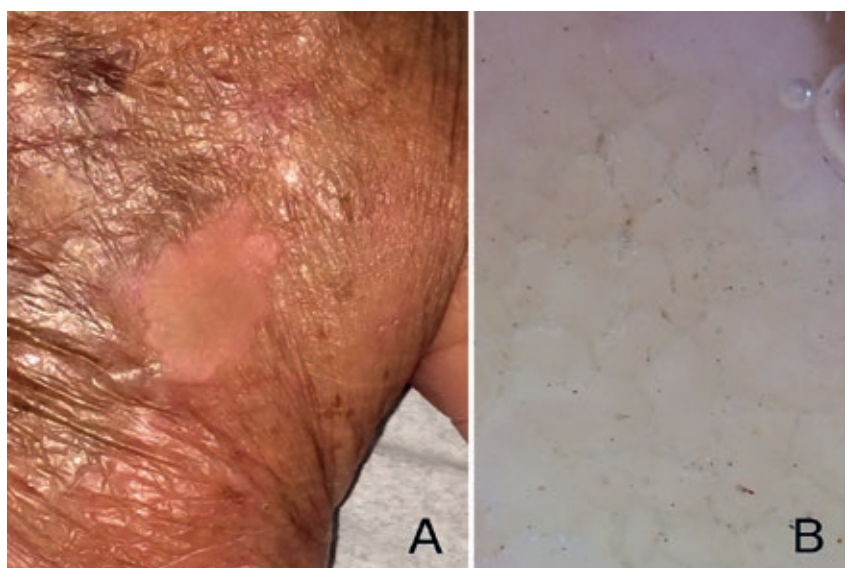

Fig 6 - Common wart. A) Hyperkeratotic plane plaque on the dorsal surface of the right hand; B) Vascular pattern of dotted and hairpin vessels was seen on dermoscopy, supporting the clinical diagnosis. structureless area with multiple blood spots, allowing the diagnosis of a plantar wart (Fig. 7).

Plantar warts lack the typically dotted or comma-like vessels seen in palmar warts. Blood spots are a helpful dermoscopic criterion to distinguish plantar warts from callus, which usually lack this feature, while exhibiting commonly a central reddish to bluish color. ${ }^{9}$ The blood spots probably correspond to blood leak, caused by the chronic high blood pressure at this location.

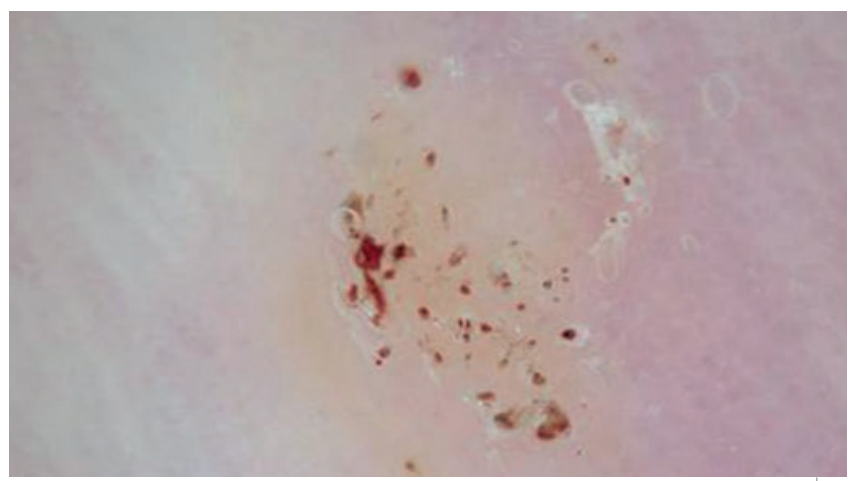

Fig 7 - Plantar warts. Dermoscopy disclosed a yellowish structureless area with multiple blood spot.

\section{Cutaneous leishmaniasis}

A 26 years-old female presented to our clinic with a 4-month history of left malar erythema, beginning weeks after travelling to Brasil. Erythema slowly progressed into a papule and then a red, asymptomatic nodule (Fig. 8A and 8B).

Dermoscopy showed multiple linear-irregular vessels and yellow globular structures known as "yellow tears" (Fig. 8C). These features allowed the diagnosis of an early localized cutaneous leishmaniasis, which was confirmed after biopsy and histopathological examination. ${ }^{10}$ The "yellow tears" correspond to the follicular plugs seen on histopathology, being highly suggestive of cutaneous leishmaniasis. ${ }^{10}$ 


\section{Dermatoscopia}

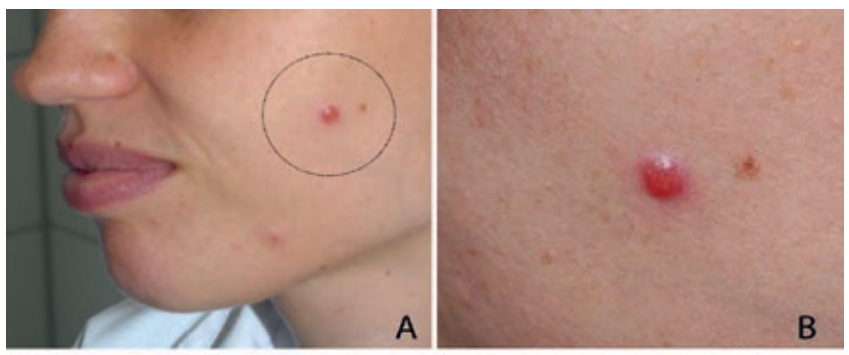

C

Fig 8 - Cutaneous leishmaniasis. A) Red nodule on the malar region; B) Detail of the clinical features; C) Dermoscopy showing multiple linear-irregular vessels and yellow globular structures known as "yellow tears", pointing to the diagnosis of early cutaneous leishmaniasis.

Leishmaniasis is a protozoan infection caused by several species of the genus Leishmania, transmitted by sandflies of the genus Phlebotomus and Lutzomiya. In 2009, a Spanish group described the dermoscopic patterns of cutaneous leishmaniasis. ${ }^{11}$ In our case, dermoscopy was, therefore, determinant in the decision to take a biopsy and provided additional clues to search for clinical and epidemiological data to perform the correct diagnosis.

\section{CONCLUSION}

Dermoscopy is a useful, fast and reliable technique for the diagnosis of skin infections and infestations, with the adequate integration of all clinical data.
As novel data is gathered in the field of entomodermoscopy, the dermoscope is increasingly accepted as an irreplaceable technique to aid in the clinical diagnosis and therapy monitoring. Allowing the study of structures invisible to the naked eye, it forms a link between macroscopic clinical dermatology and microscopic dermatopathology.

\section{REFERENCES}

1. Tschandl P, Argenziano G, Bakos R, Gourhant JY, Hofmann-Wellenhof R, Kittler $\mathrm{H}$ et al. Dermoscopy and entomology (entomodermoscopy). J Dtsch Dermatol Ges. 2009; 7:589-96.

2. Park JH, Kim CW, Kim SS. The diagnostic accuracy of dermoscopy for scabies. Ann Dermatol. 2012; 24:194-9. 3.

3. Argenziano G, Fabbrocini G, Delfino M. Epiluminescence microscopy. A new approach to in vivo detection of Sarcoptes scabiei. Arch Dermatol. 1997; 133:751-3.

4. Zalaudek I, Argenziano G. Images in clinical medicine. Dermoscopy of nits and pseudonits. N Engl J Med. 2012; 367:1741.

5. Zaballos P, Ara M, Puig S, Malvehy J. Dermoscopy of molluscum contagiosum: a useful tool for clinical diagnosis in adulthood. J Eur Acad Dermatol Venereol. 2006; 20:482-3.

6. Hoyt BS, Tschen JA, Cohen PR. Molluscum contagiosum of the areola and nipple: case report and literature review. Dermatol Online J. 2013;19:18965.

7. Lallas A, Zalaudek I, Argenziano G, Longo C, MoscareIla E, Di Lernia $V$, et al. Dermoscopy in general dermatology. Dermatol Clin. 2013;31:679-94.8.

8. Zalaudek I, Giacomel J, Cabo H, Di Stefani A, Ferrara $G$, Hofmann-Wellenhof R, et al. Entodermoscopy: a new tool for diagnosing skin infections and infestations. Dermatology. 2008; 216:14-23.

9. Bae JM, Kang H, Kim HO, Park YM. Differential diagnosis of plantar wart from corn, callus and healed wart with the aid of dermoscopy. Br J Dermatol. 2009; 160:220-2. 10.

10. Ayhan E, Ucmak D, Baykara SN, Akkurt ZM, Arica M. Clinical and dermoscopic evaluation of cutaneous leishmaniasis. Int J Dermatol. 2015; 54:193-201.

11. Llambrich A, Zaballos P, Terrasa F, Torne I, Puig S, Malvehy J. Dermoscopy of cutaneous leishmaniasis. $\mathrm{Br} \mathrm{J}$ Dermatol. 2009; 160:756-6. 